\title{
TELEWIZJA, SLODYCZE I ZDROWIE. O SPRAWCZOŚCI DZIECI I NAPIĘCIACH W PRAKTYKACH ŻYCIA CODZIENNEGO W KONTEKŚCIE PROGRAMÓW PROMOCJI ZDROWIA
}

\begin{abstract}
Abstrakt. W tekście prezentuję rezultaty badań prowadzonych w ramach projektu badawczego, realizowanego przez Interdyscyplinarny Zespół Badań nad Dzieciństwem UW, Zdrowie w opiniach dzieci - ujęcie childhood studies. Głównym celem projektu jest odczytanie znaczeń, jakie nadają kwestiom związanym ze zdrowiem (lub jego brakiem) dzieci w wieku wczesnoszkolnym (8-11 lat). Pokazuję, jak dzieci, jako społeczni aktorzy, radzą sobie z nowoczesnymi wymaganiami dotyczącymi ciała i nową strukturą odpowiedzialności związaną z traktowaniem dzieci jako przekaźników wiedzy o zdrowych nawykach żywieniowych i stylach życia. Przedstawiam także pokrótce, jak dzieci definiują zdrowie i czym dla nich jest niezdrowe zachowanie. Ze względu na to, że obok oczywistych skojarzeń ze zdrowiem - takich jak ruch na świeżym powietrzu i jedzenie warzyw oraz owoców - jednym z głównych elementów opowieści o zdrowiu okazał się telewizor, komputer i inne tego typu urządzenia, pytam o znaczenia, jakie nadają dzieci mediom w kontekście zdrowia. Skupiam się na tym, jak łączą je z problematyką zdrowia, a także, co o koncepcjach zdrowia i ciała mówi przywoływanie w tym kontekście praktyk związanych z oglądaniem telewizji. Ponadto wskazuję, że włączanie w dyskurs zdrowotny telewizji, komputera, tabletu itp. wynika z niedualistycznego podejścia dzieci do ciała i zdrowia. W ich wizji zdrowie jest nierozerwalnie związane z moralnością, edukacją i estetyką.

Choć badane dzieci przejmują wiele narracji związanych ze zdrowiem dystrybuowanych przez instytucje edukacyjne i wydają się doskonale znać zasady zdrowego żywienia i te związane z dbaniem o zdrowie i ciało, tworzą zdrowotne narracje na własnych zasadach. $Z$ jednej strony więc są posłusznymi odbiorcami programów profilaktyki zdrowotnej (wiedzą, co jest zdrowe), z drugiej pozostają członkami plemienia dzieci, które swoją dziecięcość realizują przez praktyki uznawane za niezdrowe i „niedorosłe”. Z badań wyłania się więc obraz dziecka podzielonego: wiedzącego, co robić, by być zdrowym, a jednocześnie praktykującego „niezdrowe” działania, na co pozwala mu status bycia dzieckiem.
\end{abstract}

Słowa kluczowe: zdrowie, dzieci, badania nad dzieciństwem, media.

* Dr hab., Instytut Etnologii i Antropologii Kulturowej, Uniwersytet Warszawski, ul. Żurawia 4, 00-503 Warszawa; e-mail: m.walkowicz@uw.edu.pl 


\section{Wprowadzenie}

Polskie dzieci, tak samo jak dorośli i dzieci w innych europejskich krajach, są obiektem nowoczesnych praktyk dyscyplinarnych i od nich także wymagane jest traktowanie ciała jako projektu przyszłości (np. S c hilling 2008, 2010; D w o r k in 2000; Gi dden s 2002). Nowoczesne ciało, jak wskazuje wielu teoretyków współczesności, musi być standaryzowane, normalizowane i regulowane przez diety, zabiegi higieniczne czy ćwiczenia fizyczne. Dotyczy to zarówno ciał dorosłych, jak i tych jeszcze ,niepełnych”. Jednym z podstawowych narzędzi działania nowoczesnej biopolitycznej władzy jest pojęcie normy. Normatywne spojrzenie na dziecko zaowocowało stworzeniem rozmaitych tabel, takich jak siatki centylowe, opisujących prawidłowy, zdrowy przebieg procesu rozwoju, a dostosowanie dziecka do ustanowionych norm stało się podstawowym zadaniem rodziców, personelu medycznego, instytucji edukacyjnych (Buliński 2002; Rose 1999: 154). Ma to również na celu stopniowe niwelowanie „braków”, jakimi dziecko odznacza się, w społecznym oglądzie, w stosunku do dorosłych (J a c y n o, S zul ż y cka 1999). Dzisiejsze dziecko może być postrzegane już nie tylko jako wybrakowane, niepełne, ale również jako posiadające potencjał zmiany praktyk społecznych.

W szkołach od kilku lat bardzo istotnym elementem wychowawczym są programy promocji zdrowia, rozumianej przede wszystkim jako popularyzacja zdrowego żywienia i aktywności fizycznej. Edukacja zdrowotna wpisana jest w podstawę programową (por. K a p u ś c iń s k a 2011), ponadto w bardzo wielu warszawskich szkołach podstawowych - jak można wnosić na podstawie analizy ich stron internetowych - realizowany jest któryś z dodatkowych programów, np.: „Zdrowo jem, więcej wiem”, „Wiem, co jem”, „Szklanka mleka”, „Owoce w szkole” czy „Lekki tornister”; część szkół objęta jest też programem „Szkoła Promująca Zdrowie”, realizowanym w ramach Europejskiej Sieci Szkół dla Zdrowia w Europie, działającej w wyniku porozumienia WHO, Rady Europy i Komisji Europejskiej ${ }^{1}$ Przez edukację szkolną promotorzy zdrowia starają się wpłynąć na zachowania rodziny. Jednocześnie coraz popularniejszy jest marketing oparty na odwoływaniu się do kwestii zdrowotnych. Dzieci mogą spotkać się z nim za pośrednictwem mediów, reklam czy innych praktyk związanych z byciem członkiem kultury konsumpcyjnej (por. np. kampanię sieci sklepów Biedronka pt. Gang Świeżaków ${ }^{2}$ (http://gangswiezakow.biedronka.pl/). Ten rodzaj biopolityki (rozumianej za F o u c a u l te m jako „poddanie zjawisk właściwych życiu gatunkowemu człowieka wiedzy i władzy", 1995: 124) może wprowadzać nowe napięcia w rodzinie i dziecięcej codzienności. Jest też istotnym czynnikiem wpływającym na definicje zdrowia i podejście do niego różnych aktorów społecznych.

${ }^{1} \mathrm{~W}$ grudniu $2015 \mathrm{w}$ województwie mazowieckim było to 87 szkół. Więcej o programie zob. https://www.ore.edu.pl/component/ content/article?id=249 [dostęp: 24.10 .2016 ].

${ }^{2}$ http://gangswiezakow.biedronka.pl [dostęp: 24.10.2016]. 


\section{Metoda}

W tekście prezentuję rezultaty badań prowadzonych w ramach projektu badawczego, realizowanego przez Interdyscyplinarny Zespół Badań nad Dzieciństwem UW, Zdrowie $w$ opiniach dzieci - ujęcie childhood studies ${ }^{3}$. Głównym celem projektu jest odczytanie znaczeń, jakie nadają kwestiom związanym ze zdrowiem (lub jego brakiem) dzieci w wieku wczesnoszkolnym (8-11 lat).

Badania prowadzone są od końca 2015 r. i objęły dotychczas 49 dzieci ze szkół publicznych i społecznych w różnych dzielnicach Warszawy. Do badania zaprosiłyśmy dzieci „zdrowe”, czyli takie, które nie mają chorób przewlekłych ani wymagających dłuższych pobytów w szpitalu (niemniej mam pełną świadomość wątpliwości, które mogą się pojawić co do używania kategorii „zdrowy” we współczesnym społeczeństwie). Choć naszym założeniem jest objęcie badaniem dzieci o zróżnicowanym statusie społeczno-ekonomicznym, w większości, jak dotąd, rozmawiałyśmy z osobami, które można by zaliczyć do tzw., szeroko pojętej, klasy średniej; nie było więc wśród nich dzieci z rodzin o bardzo niskim kapitale ekonomicznym czy symbolicznym ${ }^{4}$. $Z$ naszymi rozmówcami spotykałyśmy ${ }^{5}$ się najczęściej w niewielkich (3-5 osób) grupach fokusowych, w większości przypadków w domu któregoś z uczestników lub, rzadziej, w domu kultury czy tzw. ognisku pracy pozaszkolnej. Badania prowadziłyśmy zgodnie z założeniami studiów nad dzieciństwem (np. Christen sen, Jame s 2008; James, James 2008), co oznacza przede wszystkim zwrócenie szczególnej uwagi na etyczną stronę badań, w tym uzyskanie świadomej zgody na badania nie tylko od rodziców, lecz także od dzieci (por. Maci i jewska-Mroczek, R e imann 2016). Istotnym zadaniem w opisywanym projekcie było wykorzystanie takich narzędzi badawczych, które pozwalają badanym podmiotom jak najpełniej wyrażać opinię i dzielić się swoją wiedzą, a przy tym zostać zrozumianymi i adekwatnie opisanymi przez badaczy. Biorąc pod uwagę kompetencje komunikacyjne dzieci, a także samych badaczy w relacji badawczej z dziećmi, stosujemy metody partycypacyjne, czyli wielokierunkowe badania z wykorzystaniem zróżnicowanych metod i technik badawczych, w szczególności takich jak: działania plastyczne, fotografowanie, tworzenie scenek rodzajowych (np. wizyta u lekarza), opowiadanie historii.

Podczas trwających około 2 godzin spotkań dzieci rysowały, wyklejały, czasem fotografowały mieszkanie, w których odbywały się warsztaty, a przede wszystkim rozmawiały ze sobą i z nami. Cztery aktywności szczególnie dobrze

${ }^{3}$ Projekt został sfinansowany ze środków Narodowego Centrum Nauki przyznanych na podstawie umowy $\mathrm{nr}$ 2014/15/B/HS3/02477.

${ }^{4}$ Trzeba jednak zaznaczyć, że nie we wszystkich przypadkach mamy informację co do statusu społeczno-ekonomicznego rodziny.

${ }^{5}$ Badania prowadzą ze mną także dr Ewa Maciejewska-Mroczek i Maria Reimann, obie reprezentują Interdyscyplinarny Zespół Badań nad Dzieciństwem UW. 
pokazały stosunek dzieci do kwestii związanych ze zdrowiem. W pierwszej prosiłyśmy dzieci o narysowanie planu ich domu i zaznaczenie w nim miejsc, które kojarzą się im ze zdrowiem (rys. 1). W drugim ćwiczeniu nasi rozmówcy mieli za zadanie narysować człowieka zdrowego i niezdrowego. Ponadto dzieci uzupełniały tabelkę z czterema polami: „lubię - zdrowe”, „nie lubię - zdrowe”, „lubię - niezdrowe”, „nie lubię - niezdrowe” (por. rys. 2). Na koniec każdego spotkania prosiłyśmy, by stworzyły ulotki dla innych dzieci, dotyczące tego, jak dbać o zdrowie (rys. 3).

Podczas tzw. fokusów (FGI, zogniskowanych wywiadów grupowych) powstało wiele prac plastycznych - rysunków, wycinanek, z których trzy zostaną zaprezentowane poniżej. Warto tu jednak podkreślić, że nie traktuję ich jako autonomicznych, mówiących same przez się wytworów dziecięcej wyobraźni. W moim rozumieniu można je odczytywać jedynie w kontekście, wraz ze słowami, gestami, wyrazem twarzy dzieci podczas tworzenia prac, a potem ich omawiania. W większości przypadków rysunki służyły więc jako pretekst do opowiedzenia swojej historii czy opinii na dany temat, czasem były doskonałym uzupełnieniem przekazywanej werbalnie i pozawerbalnie treści. Prace plastyczne traktuję więc tak, jak proponuje Cindy Dell C la rk, w kategoriach czasownikowych, a nie rzeczownikowych. „Rzecznicy podejścia do rysunku jako do czasownika są zainteresowani procesem, w którym dziecko za pośrednictwem sztuki nadaje znaczenia, oraz jego interpretacją swojej pracy" (2011: 142).

Celem niniejszego tekstu jest pokazanie, jak dzieci, jako społeczni aktorzy, radzą sobie z nowoczesnymi wymaganiami dotyczącymi ciała i nową strukturą odpowiedzialności związaną z traktowaniem dzieci jako przekaźników wiedzy o zdrowych nawykach żywieniowych i stylach życia, pożądanych przez biopolityczne dyskursy. Przedstawię także pokrótce, jak dzieci definiują zdrowie i czym dla nich jest niezdrowe zachowanie. Ze względu na to, że obok oczywistych skojarzeń ze zdrowiem - takich jak ruch na świeżym powietrzu i jedzenie warzyw oraz owoców - jednym z głównych elementów opowieści o zdrowiu okazał się telewizor, komputer $\mathrm{i}$ inne tego typu urządzenia, zadam pytanie o znaczenia, jakie nadają dzieci mediom w kontekście zdrowia. Skupię się na tym, jak łączą je z problematyką zdrowia, a także, co o koncepcjach zdrowia i ciała mówi nam przywoływanie w tym kontekście praktyk związanych z oglądaniem telewizji.

\section{Technofobie i idealizacje}

Na początku spotkania dzieci rysowały swoje domy. Czasem były to bogate kolorowe ilustracje, innym razem schematyczne rysunki jednym kolorem. Plany rzadko były dla nas i innych uczestników badania czytelne, dlatego dzieci chętnie opowiadały, co zaznaczyły. Mogło tu znaleźć się niemal wszystko: pokój „niezdrowej" siostry, która całymi dniami gra na komputerze; kuchnia, w której mama 
przyrządza „domowe pesto”; drzwi balkonowe, które wskazują na istotność ruchu na świeżym powietrzu; rośliny, bo ,podobno jak się wdycha zapach rośliny, to jakoś to tak uspokaja czy coś takiego"; półka z książkami, które są zdrowe, bo czytając, „ćwiczy się mózg”; łóżko, na którym mama szepcze miłe słowa na chore ucho córki. Niemal zawsze przy omawianiu planów domów szybko pojawiał się temat telewizora czy komputera (zob. rys. 1).

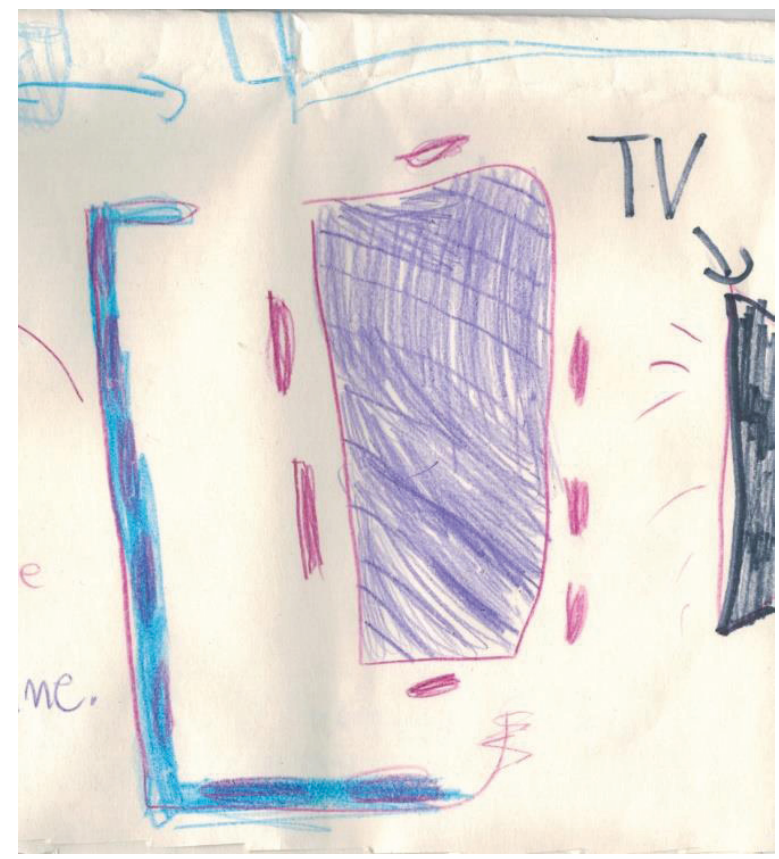

Rys. 1. Fragment planu domu narysowanego przez dziewczynkę, 9 lat, uczącą się w państwowej szkole w Warszawie, FGI, kwiecień 2016

Badaczka: Co takiego jest $w$ domu, co nie jest zdrowe?

D: Na pewno telewizor! Na czarno zaznaczyłam.

Badaczka: A dlaczego jest niezdrowy telewizor?

M: Bo jak się siedzi godzinami przed telewizorem, to bola oczy $i$ boli glowa.

J: I jeszcze tablet i telefon, dlatego że to się świeci i jeżeli ktoś... [...] Bo potem strasznie bola oczy, jeżeli godzinami się patrzy w to świecace miejsce.

Niezdrowe są więc także inne urządzenia elektroniczne, takie jak komputer, tablet, iPod, które służą dzieciom do oglądania bajek, filmów lub do grania.

M: To jest mój dom, od góry. Tu jest komputer. Komputer jest niezdrowy.

Badaczka: Dlaczego komputer jest niezdrowy?

M: Bo psuje oczy.

Badaczka: I dlaczego jeszcze?

M: Bo wytwarza promieniowanie.

Badaczka: A na co źle działa promieniowanie? 
M: Nie mam bladego pojęcia.

Badaczka: A jak ci się wydaje?

Badaczka: Co to jest w ogóle promieniowanie?

M: Nie mam pojęcia.

I: Ale jakie? Ultrafioletowe? Czy jakie? Czerwone...

Badaczka: Nie wiem, takie, co wytwarza komputer.

I: Czerwone najsilniejsze jest. [...]

Badaczka: A komputer jakie wytwarza?

I: Nie wiem, czy w ogóle jakieś wytwarza. Na pewno zużywa dużo energii, która jest potrzebna do życia.

Dzieci biorące udział w badaniu uznają bez wahania, że telewizja i komputer są niezdrowe. Nie podają tej wiedzy w wątpliwość. Dlaczego są niezdrowe? Odpowiedź na to pytanie już tak oczywista dla nich nie jest. W pierwszym odruchu najczęściej wskazują, że telewizja i komputer są niezdrowe, bo psują oczy. Dziewczynka przyznaje: bo się od tego psuja oczy, a jak ma się to za głośno, to też uszy. Takie ugruntowanie problemu w biologii, $\mathrm{w}$ ciele, ułatwia rodzicielski przekaz wychowawczy i co za tym idzie racjonalizację przez dzieci zakazów dotyczących korzystania z mediów. Czy jednak o oczy tylko chodzi? Abstrahując od technicznych parametrów ekranu i medycznych badań dotyczących wpływu ekranów na wzrok, które nie są tak oczywiste (por. Si e g e n thale r i in. 2012), wydaje się, że jest to jedynie pewien pretekst czy też skrót myślowy. Dzieci także przeczuwają, że to nie tylko o wzrok chodzi. Kiedy je dopytujemy, dlaczego telewizja jest niezdrowa, mówią o uzależnieniu od komputera, o niemożności oderwania się od telewizji. Telewizja zabiera według nich czas, który można by spożytkować na bieganie po dworze (co zawsze jest definiowane jako zdrowe), lub wręcz jakiś rodzaj energii, która jest potrzebna do życia. Czasem nasi rozmówcy odnoszą się do samych treści przekazywanych za pośrednictwem telewizji czy Internetu, które mogą je wystraszyć, powodować złe sny. W naszych rozmowach pojawiło się też słowo zamulenie.

David B u c kin g h a m, wskazujący tendencje deterministyczne w opisach technologii i krytykujący przecenianie jej wpływu na życie codzienne dzieci, zauważa:

Telewizja, konsola do gier czy komputer stają się nader wygodnym obiektem koncentracji naszych niepokojów i frustracji - związanych z przemocą, zepsuciem obyczajów, komercjalizmem czy seksizmem lub też z upadkiem tradycyjnych poglądów na dzieciństwo i życie rodzinne (2008: 155).

Można powiedzieć, że dzieci internalizują lęki rodziców, które z kolei są ucieleśnionymi lękami istniejącymi w kulturze. To znane lęki, które możemy, upraszczając, opisać terminem technofobii. W bardzo ciekawym tekście Anna Landau-Czajka pokazuje, że są one mocno ugruntowane w naszej kulturze i wiążą się z ogólną niechęcią rodziców do wszelkich „nowinek”, którymi interesują się ich dzieci (Landau-Czajka 2003: 231). W przeszłości jako niebezpieczną rozrywkę wskazywano m.in. czytanie książek. Dzisiaj jest to zajecie pożądane, 
według wielu z naszych rozmówców służące zdrowiu, a według jednego z nich nawet neutralizującego zły wpływ oglądania telewizji i grania na komputerze:

Chx: Jak mi się nudzi granie na komputerze, to ja mam taki obowiąek, jeśli nie zapomnę o tym, to ja mam taki obowiązek, że zawsze wieczorem czytam książke.

Badaczka: Aha, ale to jest obowiazek, bo rodzice ci tak...?

Chx: Nie, po prostu sobie sam tak wyznaczytem, bo uważam, że to jest dobre na przyktad po graniu i po całym dniu sobie poczytać książke... [...] Pewnie nie będzie, nie będzie się miało jakiś snów złych, takich, że no, nie wiem, że będzie ci się coś śniło złego, że coś cię goni, że coś w tym stylu, tylko jakby w śnie chciat to, że se wymyślasz dalszy, dalszy ciag danej ksiażki, że na przykład, ja tak sobie myślę.

Mamy tu wyraźną opozycję: książki jako coś dobrego, „zdrowego” - na wielu mapach rysowanych przez dzieci i robionych przez nie fotografiach książki zajmowały centralne miejsce jako elementy ,zdrowe” - oraz telewizji jako rozrywki niewłaściwej, rzadko wartościowej. Podobna opozycja ujawnia się w stosunku do gier komputerowych - te, niemal zawsze szkodliwe, przeciwstawiane są grom planszowym":

M: [komentując swoją ulotkę] tutaj uprawiaj dużo sportu, chodźmy do lasu i grajmy w gry planszowe.

Badaczka: A dlaczego gry planszowe sa zdrowe?

M: Bo nie tak jak gry komputerowe.

J: Bo rozwijają umyst. Czasami sq takie gry, które sa bardzo trudne.

Wyniki naszych badań potwierdzają tezę L a n d a u - C z a j k i, która zaznacza:

[...] u podłoża krytyki ,nowomodnych rozrywek” leży w gruncie rzeczy niezmienna od stuleci podejrzliwość wychowawców co do wszelkiej rozrywki, która [...] jest obecnie uznawana za zbędną i niepożądaną. U podstaw krytyki leży założenie, jawne w pedagogice dziewiętnastowiecznej i ukryte obecnie, że młody człowiek nie powinien „marnować czasu”, a każda chwila jego życia powinna być wykorzystana w sposób wartościowy (2003: 245-264).

\section{Sprawcze praktykowanie niesprawczości}

Dzieci biorące udział w naszych badaniach definiują komputer czy telewizję jako przedmioty, które mogą zdobyć nad nimi kontrolę. Jak pisze B u c k in g h a m:

Niezależnie od tego, czy wpływ nowych mediów na dzieci ocenia się jako pozytywny czy negatywny, istnieje dość jednolity pogląd, że media dysponują nadzwyczaj potężnymi możliwościami modelowania świadomości dzieci, określania ich tożsamości i dyktowania wzorców powielanych często w codziennym życiu (2008: 151).

Dzieci zatem wobec hegemonii telewizji i innych mediów czuć są postrzegane jako bezbronne. Mówiąc jednak o ich „niezdrowiu”, opowiadają o tym, jak z tych przedmiotów korzystają. Nie wiąże się to jednocześnie ze skrępowaniem $\mathrm{z}$ ich strony czy poczuciem dysonansu poznawczego. To rodzice mają dbać o to, 
by dzieci nie zostały przez telewizję ,wciągnięte”, to oni są odpowiedzialni. Dając sobie więc przyzwolenie na korzystanie z mediów i bycie kontrolowanym przez dorosłych, niejako sprawczo odbierają sobie swoją sprawczość. Podobnie jak ich rodzice, definiują dziecko jako istotę bezbronną, podatną na zranienie, niemającą kompetencji, by adekwatnie odpowiedzieć na „zagrożenia” płynące z ekranu (por. A sh 2013; P otter 2013: 64-65). Jeden z chłopców przyznaje, że kiedyś grał Aż do zmęczenia oczu. Jak mi się raz zdarzyło, że miatem komputer i przez sześć godzin gratem.

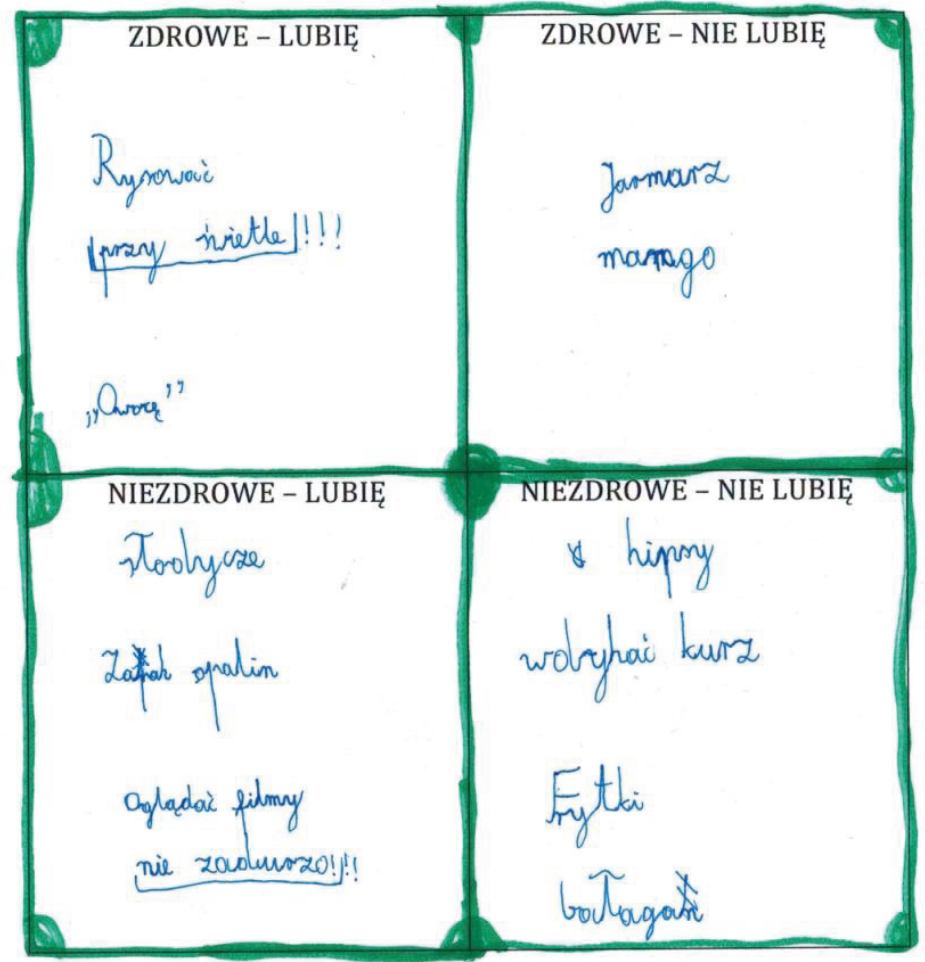

Rys. 2. Tabelka uzupełniona przez chłopca, 9 lat, uczącego się w szkole społecznej w Warszawie, FGI, maj 2016

Podobnie czynią, kiedy podczas fokusów czy wywiadów pogłębionych mowa o jedzeniu słodyczy. Zawsze słyszymy, że są one niezdrowe, że nie powinno się ich jeść w nadmiarze lub że w ogóle nie powinny znajdować się w jadłospisie dziecięcym. Ale oczywiście dzieci słodycze jedzą i przyznają się do tego. Jedzą też pizzę, frytki i chipsy, które w tabelkach znajdują się często w rubryce „niezdrowe - lubię" (rys. 2).

Jak radzą sobie więc z tą dwoistością? Częściowo odpowiedź znajdziemy w wypowiedzi dziewięciolatki, zastanawiającej się nad pytaniem, które zadałaby człowiekowi wiedzącemu wszystko o zdrowiu: 
Ja bym zadała pytanie, czy da się przeżyć bez słodyczy i bez na przykład takich czynności jak granie na komputerze... Czy da się jeść tylko zdrowe rzeczy, na przyklad nie jeść hamburgerów, na przykład zrobić sobie taki test, żeby na przykład przez dwa tygodnie nie jeść takich rzeczy. Czy da się to zrobić? [...] Ja myślę, że by się tak dało. Tylko nie wiem, czy akurat przez dwa tygodnie. Bo nawet jak jakiś człowiek nie je za dużo słodyczy, to zdarza mu się coś zjeść. Może nie dużo, ale zdarza mu się coś. Ja bym może tydzień wytrzymała bez słodyczy i takich przyjemności, ale czy bym wytrzymała dwa tygodnie, to chyba nie... [...]

D: Tak dzieci maja!

J: Dla mnie tym, że jednak dorośli bardziej panują nad tym. Że jak chcą coś słodkiego, to jednak nie wezma tak szybko tego cukierka. I dorośli, no nie wszyscy, ale niektórzy, jedza rzadziej te cukierki... A dzieci lubia bardzo stodkie, bo stodkie jest dobre, a ... znaczy dorośli nie mówię, ze nie lubia, tylko po prostu, bo lubia, tak jak dzieci, tylko po prostu z umiarem, podchodza do tego z umiarem...

Dzieci więc „tak mają”, według naszych rozmówców, nie znają umiaru, co pozwala im - mimo przyswojenia wiedzy ze szkolnych i pozaszkolnych programów promocji zdrowia - cieszyć się słodyczami, grami na komórkach i bajkami w telewizji. Dzieci podczas badań z nami deklarują, że potrzebują swoich rodziców, by ci sprawowali kontrolę nad ich praktykami. To nie jest jeszcze wiek, w którym młodzi ludzie („gimnazjaliści”), jak mówią nasi rozmówcy, mają swoje pieniądze, więc ,jedzą chipsy i piją colę", uznając, że mogą sami decydować o tym, co jest dla nich dobre. W tym niebraniu pełnej odpowiedzialności za praktykowanie niezdrowych zachowań można dostrzec nie tyle bierność badanej grupy, ile ich aktywną rezygnację z trudnej odpowiedzialności. Zwłaszcza ważne wydaje się to w sytuacji, kiedy ta odpowiedzialność jest im narzucana m.in. przez różne programy zdrowotne prowadzone w szkołach. Dzieci bowiem, zgodnie z filozofią programów promocji zdrowia, mają za zadanie wprowadzać do domu wiedzę dotyczącą dobrych nawyków żywieniowych czy innych praktyk prozdrowotnych wyniesioną ze szkoły. ,[S]zkoła jest siedliskiem, w którym uczniowie i pracownicy spędzają dużą część swojego życia i w którym «tworzone jest zdrowie»" - czytamy w Koncepcji i zasadach tworzenia szkoły promujacej zdrowie (Wo y na row ska, S ok ołow ska 2006: 9). „[S]zkoła - czytamy dalej - jako powszechna i masowa organizacja, umożliwia systematyczną edukację zdrowotną młodego pokolenia i pośrednio rodziców. Uważa się, że szkolna edukacja zdrowotna jest najbardziej opłacalną, długofalową inwestycją w zdrowie społeczeństwa" (Wo y n a row s k a, S o k oło w s k a 2006: 9). Widać więc, że na dzieciach spoczywa obowiązek edukowania rodziny i tym samym zmiany praktyk codziennych. Są podwójnie odpowiedzialne: za swoje zdrowie i za zdrowie rodziny. Odpowiedzią na ten nakaz płynący od promotorów zdrowego stylu życia jest niekoniecznie pouczanie rodziców i faktyczne upominanie się dziecka o zmianę rodzinnych nawyków zakorzenionych w codzienności, lecz negocjacje z nimi i powrót do przestrzeni rodzicielskiej odpowiedzialności. Myślę, że... to jest czasami troche też kwestia twojego... tego, co dostajesz do jedzenia... troche też twoich rodziców... bo jeżeli twoi rodzice daja ci cały czas stodycze i nagle, 
gdy jesteś sama zostajesz ... i wszyscy ci mówia, żebyś... i chcesz zostać zdrowa, tak... to jesteś przyzwyczajona, jakby uzależniona od tych słodyczy, coca coli i tak dalej... Dlatego tym dzieciom, które rodzice na przyklad wychowuja na samych stodyczach... sa o wiele trudniej być zdrowym - opowiada dziewięciolatka, która jednocześnie przyznała się do kontrolowania swojego ciała i zwracania uwagi na wielkość brzucha, kiedy ogląda się w lustrze.

Teoretycy skupieni wokół tzw. childhood studies podkreślają, że dziecko należy traktować jako aktora społecznego, posiadającego sprawczość, a nie biernego odbiorcę treści proponowanych przez kulturę konsumpcyjną i różne modele wychowawcze (np. B rag g, K e hily 2013). Jak, pozostając w tym paradygmacie, rozumieć to dziecięce wycofywanie się z odpowiedzialności za swoje zdrowie i mimo wiedzy o tym, co jest zdrowe, a co nie, wybieranie słodyczy, gier komputerowych i bajek w telewizji? Nakaz odpowiedzialności za zdrowie rodziny, który spoczywa na dzieciach, zostaje zneutralizowany innym nakazem: realizacji swojej dziecięcości. Między tymi dwoma kulturowymi przymusami pojawia się napięcie. Zauważa je również Nicoletta D i a s i o, która badała fenomen przekąsek wśród francuskich i włoskich uczniów:

Obowiązek bycia odpowiedzialnym za siebie i dostosowywania się do moralnej technologii jest w napięciu z nakazem zabawy i przyjemności, które charakteryzują dzieciństwo w tzw. społeczeństwie zachodnim (2010: 63) ${ }^{6}$.

Bycie dzieckiem oznacza więc bycie nieodpowiedzialnym, spontanicznym, przekraczającym granice. Jednocześnie bycie współczesnym dzieckiem oznacza wprowadzanie do swoich i rodziny codziennych praktyk nowoczesnych reżimów ciała związanych z dbaniem o zdrowie, rozumiane jako dobre odżywianie się, bycie wysportowanym i posiadanie szczupłej sylwetki, co z kolei jest elementem odpowiedniego zarządzania przyszłością i związanymi z nią późnonowoczesnymi ryzykami (por. Di a s i o 2010; Gidd e n s 2002; B e ck 2012). Na jednym z fokusów usłyszałyśmy:

Badaczka: A kto w domu dba o zdrowie?

Dzieci, chórem: Rodzice.

M: Chyba że mama pali papierosa. Ale to tylko trzy na krzyż zapaliła. Nad morzem, zrobitem jej straszna afere, ale to straszna. Powiedziatem tacie. Powiedziatem tacie!

Badaczka 2: A dlaczego tak się zdenerwowateś, że mama zapalita?

M: Bo nie można palić!

Badaczka: Czyli to dzieci pilnuja zdrowia, tak?

J: Dzieci pilnuja! Właśnie.

${ }^{6}$ Anonimowy recenzent mojego tekstu zwraca uwagę, że „,elem współczesnego marketingu skierowanego do dzieci jest wzbudzanie w nich aspiracji do bycia dorosłymi, konsumowania dóbr, usług i przyjemności w «dorosły sposób»". Zgadzam się, że możemy obserwować takie tendencje, zwłaszcza jeśli oprzemy się na analizie treści medialnych i marketingowych, nie zmienia to jednak faktu, że cały czas dzieciństwo definiowane jest też przez inne cechy, takie jak chociażby spontaniczność i nieodpowiedzialność. 
Badaczka: Dzieci pilnuja, żeby rodzice nie robili niezdrowych rzeczy? [...]

M: Albo żeby dobrze skręcili, jak kierują.

$\mathrm{J}$ I İeby uważali, żeby nie trafiali w samochody ani w znaki.

M: Nie, żeby dobrze skręcili. Mój tata akurat bardzo często robi coś w telefonie, ja mu mówię... [...] Nie może się oderwać.

$\mathrm{J}:$ Mój tata też.

Badaczka 2: Czyli musicie trochę pilnować tych rodziców...

$\mathrm{J}$ : Ale to mama też troche pilnuje tatę.

Dzieci wiedzą więc, że mogą być odpowiedzialne w pewnym stopniu za postępowanie rodziców. Podczas naszych rozmów wykazywały się także świadomością odpowiedzialności za swoją przyszłość, zwłaszcza dotyczyło to kwestii jedzenia i szczupłej sylwetki (Zdrowie też... trzeba dbać o nie... nie tak, $\dot{z} e . .$. to jest kolejna zasada zdrowia, że właśnie trzeba... nie można leżeć na fotelu cały czas przed telewizorem, tylko trzeba się ruszać - mówi jedna z naszych rozmówczyń). Niezdrowy człowiek na rysunkach dzieci był gruby, brzydki, miał hamburgera i frytki w ręku. Zdrowy był szczupły, uśmiechnięty i ładny. O projekcie swojej ulotki o zdrowiu jedna $\mathrm{z}$ dziewczynek powiedziała: A wie pani co ja zrobię? Wytnę najpiękniejsze dziewczyny z tej gazety i wkleję: A to sa te co dbaty o zdrowie! A takie najbrzydsze, to powiem: a to te co nie dbaty o zdrowie. Dzieci za otyłość winią nawyki żywieniowe, telewizję i komputer. Przyznają, że człowiek jest odpowiedzialny za swoje ciało i zdrowie: Mi się wydaje, że ten kto jest zdrowy, jest też wesoły. I że... ludzie trochę grubsi... tak kiedyś wyczytałam to w ksiażce i się z tym bardzo zgadzam ... że ludzie trochę grubsi sq... działaja na tej zasadzie, że... wchodza na wagę i mówiq: oj, jaki jestem gruby, ojej smutno mi, to zjem sobie batonika na pocieszenie... ojej... - jak już zjadt tego batonika-ojej, przecież ja nie mogłem zjeść tego batonika... ojej, jak mi smutno... to zaproszę kolegów i pójdziemy na pizzę.

Jak pisałam, nie oznacza to, że dzieci wprowadzają w życie nakazy przekazywane w programach promocji zdrowia i odżywiają się w pełni zgodnie z nimi - podobnie jak ich rodzice, jedzą słodycze i korzystają z tabletów. Pozwala im na to nie tylko nakaz praktykowania dziecięctwa, ale także to, co Anthony G i d d e n s (2002) nazywa kokonem ochronnym, niedopuszczającym świadomości zagrożeń, który opiera się na „podstawowym zaufaniu” dzieci w stosunku do opiekunów. Giddens pisze o świadomości dyskursywnej i praktycznej. Pierwsza odnosi się do tego, co wiemy, co możemy w refleksyjnym akcie uzasadnić i co wyraża się w dialogu czy dyskusji; druga - do tego, co zrutynizowane, nawykowe, pomaga radzić sobie z codziennością i społecznym otoczeniem. Tu mamy do czynienia z tymi dwoma typami świadomości: z dyskursywną, ale też swego rodzaju (nie) świadomością praktyczną - w dwóch znaczeniach słowa ,praktyczna”: jako rozgrywająca się w praktykach, ale też pragmatyczna, ułatwiająca codzienne funkcjonowanie i trwanie w kokonie ochronnym, który jest „,niezbędny każdej normalnej jednostce do tego, by radziła sobie ze sprawami życia codziennego" (Gid dens 
2002: 57). Trwanie w poczuciu „bezpieczeństwa ontologicznego” pozwala więc pokonać sprzeczności między wiedzą a praktykami. Ale to trwanie należy rozumieć znowu nie jako bierne przeczekiwanie i poddawanie się opiece rodzicielskiej, lecz jako sprawcze negocjowanie zakresu obowiązków i ram odpowiedzialności.

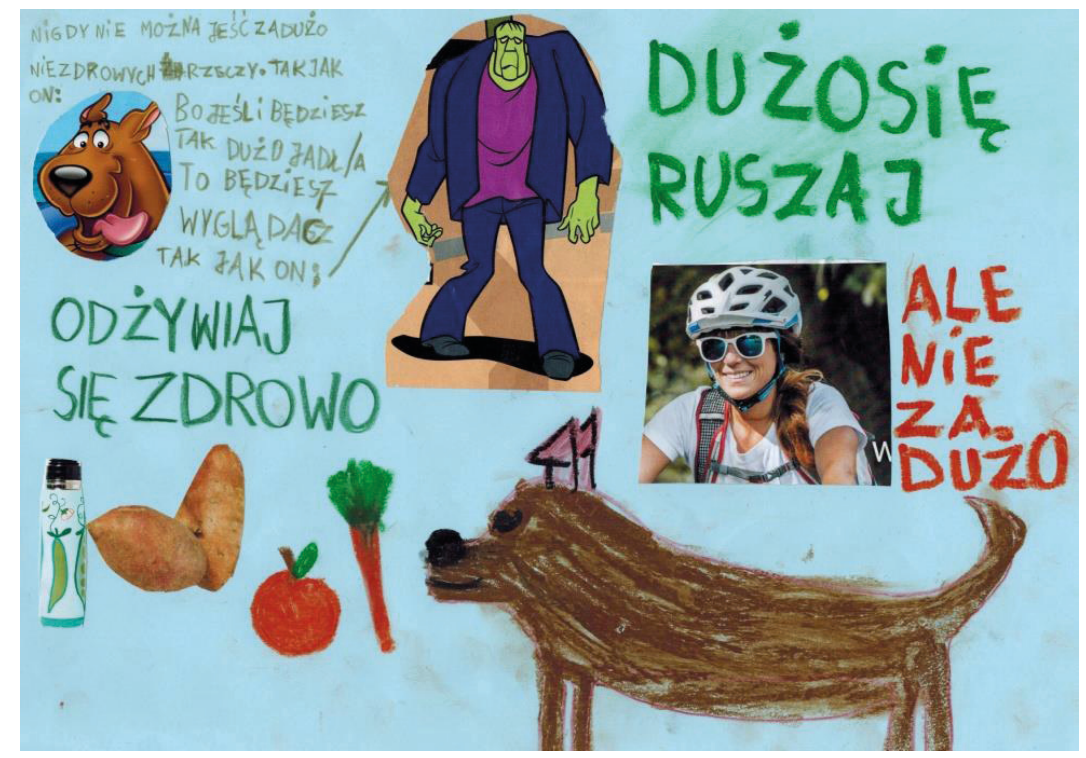

Rys. 3. Ulotka o zdrowiu narysowana przez dziewczynkę, 10 lat, uczącą się w społecznej szkole w Warszawie, FGI, maj 2016

Nie zmienia to wszystko faktu, że dzieci są uczestnikami nowoczesnej kultury ryzyka i na nie również wpływają i do nich docierają roszczenia nowoczesności dotyczące dbania o ciało i nakaz kolonizowania przyszłości poprzez działanie tu i teraz (takie jak dieta, wyrzekanie się smakołyków, regulacje dotyczące zabawy). Otyłość jest dla nich realnym strachem, a zdrowe i szczupłe ciało ważnym życiowym celem.

\section{Konkluzja}

Założeniem badawczym projektu, a jednocześnie jego rezultatem, jest rozpoznanie, że dziecko nie jest jedynie biernym uczestnikiem wydarzeń projektowanych przez dorosłych, lecz także sprawczym podmiotem mogącym wpływać na otaczające go światy, w tym związane z obszarem zdrowia i cielesności, może więc stawiać warunki i czynnie odpowiadać na nakazy i zakazy ze względu na psychologiczne wyposażenie i swoją rolę we współczesnej rodzinie. Choć dzieci w wieku wczesnoszkolnym przejmują wiele narracji związanych ze zdrowiem dystrybuowanych przez instytucje edukacyjne i wydają się doskonale znać zasady 
zdrowego żywienia i te związane $\mathrm{z}$ dbaniem o zdrowie i ciało, nadają im wiele oryginalnych, „niekanonicznych” znaczeń. Tworzą zdrowotne narracje na własnych zasadach, a jednocześnie swoją wiedzę budują na oficjalnych przekazach odnoszących się do tego, jak zdrowo żyć. Z jednej strony więc są posłusznymi odbiorcami programów profilaktyki zdrowotnej (wiedzą, co jest zdrowe), z drugiej - pozostają członkami plemienia dzieci, które swoją dziecięcość realizują przez praktyki uznawane za niezdrowe i ,niedorosłe”. Z badań wyłania się więc obraz dziecka podzielonego. Wiedzącego, co robić, by być zdrowym, a jednocześnie praktykującego „niezdrowe” działania, na co pozwala mu status bycia dzieckiem oraz relacja z rodzicami oparta na opiece i sprawczym oddaniu opiekunom sprawczości. Trzeba też zauważyć, że wiedza o zdrowiu, jeśli jest przekazywana w szkole, może zostać uznana za zewnętrzną i poddającą się kontestacji (choć dla wielu dzieci w wieku wczesnoszkolnym autorytet szkoły jest niekwestionowalny). Jeśli zaś jest przede wszystkim wiedzą od rodziców, może być negocjowana i traktowana niepoważnie, tak jak niepoważnie zakazy i nakazy zdrowotne traktują sami rodzice.

Podczas badań zaskoczyło nas ogromne znaczenie, jakie dzieci nadają w kontekście zdrowia telewizji i innym urządzeniom elektronicznym. Niewątpliwie włączanie $\mathrm{w}$ dyskurs zdrowotny telewizji, komputera, tabletu itp. wynika z niedualistycznego podejścia dzieci do ciała i zdrowia, a jednocześnie z mocno ugruntowanego w kulturze przekonania o złym wpływie mediów elektronicznych na dzieci, rozumiane jako niekompetentne, podatne na wpływy. W wizjach prezentowanych przez dzieci, co zapewne jest odbiciem rodzicielskich programów wychowawczych, zdrowie jest nierozerwalnie związane z moralnością, edukacją i estetyką. Para „zdrowy - niezdrowy” (co także ciekawe, opozycją do zdrowego był w opiniach dzieci „niezdrowy”, a nie po prostu „chory”) zdaje się zastępować pole wyznaczane przez pojęcia „grzeczny - niegrzeczny”, a jednocześnie bliska jest opozycji „odpowiedzialny - nieodpowiedzialny”. Kategoria zdrowia porządkuje to, co kiedyś należało do sfery wychowania. Zdrowie pojmowane jest więc holistycznie, nie kartezjańsko i nie biomedycznie. Wpływu na zdrowie nie mają bakterie, wirusy czy geny, lecz ma styl życia i samokontrola, tu rozumiana przede wszystkim jako umiejętność odmawiania sobie przyjemności lub znajdowania przyjemności w tym, co definiowane jako zdrowe.

$\mathrm{Z}$ jednej strony więc najdoskonalszym wcieleniem w tym nowym porządku byłoby dziecko w pełni samodyscyplinujące się, które ucieleśniło nowoczesne nakazy dotyczące ciała (nie ogląda telewizji, nie gra na komputerze, dużo się rusza i je ogromne ilości warzyw), z drugiej strony jednak pozostaje sfera dziecięcości. I to jej praktykowanie jest sprawczą odpowiedzią dzieci na reżimy ciała i zdrowia, którym są poddawane w szkole, w mediach, przy stole. 


\section{Bibliografia}

A s h J. (2013), New media and participatory cultures, [w:] S. B ragg, J. M. Ke hily (red.), Children and young people's cultural worlds, The Policy Press, Bristol, s. 219-267.

B e c k U. (2012), Społeczeństwo światowego ryzyka, Wydawnictwo Naukowe Scholar, Warszawa. B r a g g S., K e hily J. M. (red.) (2013), Children and young people's cultural worlds, The Policy Press, Bristol.

B u c k in g h a m D. (2008), Nowe media - nowe postaci dzieciństwa? Zmieniajace się środowisko kulturowe dzieci w erze technologii cyfrowej, [w:] M. J. K e hily (red.), Wprowadzenie do badań nad dzieciństwem, Wydawnictwo WAM, Kraków, s. 151-169.

B u lińs k i T. (2002), Człowiek do zrobienia. Jak kultura tworzy człowieka: Studium antropologiczne, Wydawnictwo Poznańskie, Poznań.

$\mathrm{C}$ h r i s t e n s e $\mathrm{n}$ J., J a m e s A. (red.) (2008), Research witch children: Perspectives and practices, Routledge, Abington-New York.

Clark C. D. (2011), In A Younger Voice. Doing Child-Centered Qualitative Research, Oxford University Press, Oxford-New York.

D i a s i o N. (2010), Children and Food: Ambivalent Connections Between Risk, Moral Technologies, and Fun, [w:] S. Vandam m, S. van de Vathorst (red.), Whose Weight is it Anyway?: Essays on Ethics and Eating, Acco, Leuven-Den Haag, s. 55-66.

D w o r k in R. (2000), The New Gospel of health, "The Public Interest", Vol. 141, s. 77-90.

F o u c a u $1 \mathrm{t}$ M. (1995), Historia seksualności, Czytelnik, Warszawa.

G i d d e n s A. (2002), Nowoczesność i tożsamość. „Ja” i społeczeństwo w epoce późnej nowoczesności, Wydawnictwo Naukowe PWN, Warszawa.

J a c y n o M., S z u 1 ż y c k a A. (1999), Dzieciństwo: doświadczenie bez świata, Oficyna Naukowa, Warszawa.

J a m e s A., J a m e s A. L. (2008), Key concepts in childhood studies, Sage, Los Angeles.

K a p ús c ińs k a A. (2011), Edukacja zdrowotna w podstawie programowej dla klas I-III, [w:] B. W o y n a r o w s k a (red.), Organizacja i realizacja edukacji zdrowotnej w szkole. Poradnik dla dyrektorów szkót i nauczycieli, Ośrodek Rozwoju Edukacji, Warszawa, s. 79-89.

La nd a u-C zajk a A. (2003), Zagrożenia i niebezpieczeństwa ,nowomodnych rozrywek”. Co grozi dzieciom ze strony ksiązek, teatry, filmu, telewizji, wideo, gier komputerowych $i$ wszystkiego, co uda się jeszcze wynaleźć?, [w:] M. D ą b r o w s k a, A. K l o n d e r (red.), Od narodzin do wieku dojrzatego. Dzieci i młodzież w Polsce, IAE PAN, Warszawa, s. 247-260.

M a c i e j e w s k a - M r o c z e k E., R e i m a n M. (2016), Jak zgadzaja i nie zgadzaja się dzieci. $O$ (nie)równowadze sił $i$ świadomej zgodzie w badaniach z dziećmi, „Przegląd Socjologii Jakościowej”, t. XII, nr 4, s. 42-55.

P o t t e r J. (2013), Media literacy, Sage, Los Angeles-London-New Delhi.

Ros e N. (1999), Governing the soul: The shaping of the private self, Free Association Book, London.

S chilling Ch. (2008), Kultura, ,rola chorego” i konsumpcja zdrowia, [w:] P. S z to m p ka, M. B o g u n i a - B o r o w s k a (red.), Socjologia codzienności, Wydawnictwo Znak, Kraków, s. $732-755$.

S c hilling Ch. (2010), Socjologia ciała, Wydawnictwo Naukowe PWN, Warszawa.

$\mathrm{S}$ i e g e $\mathrm{n}$ th a l e r E., B o c h u d Y., B e r g a m in P., W u r t z P. (2012), Reading on LCD vs e-link displays: effects on fatigue and visual strain, "Ophthalmic and Physiological Optic", Vol. 32, No. 5, s. 367-374.

Wo y na row s k a B., S o k oł ow s k a M. (2006), Koncepcja i zasady tworzenia szkoty promujacej zdrowie, „Edukacja Zdrowotna i Promocja Zdrowia w Szkole”, z. 10-11, s. 9-46 (dostępny na stronie Ośrodka Rozwoju Edukacji: www.ore.edu.pl). 
Magdalena Radkowska-Walkowicz

\section{TELEVISION, SWEETS, AND HEALTH. ON CHILDREN'S AGENCY AND TENSIONS IN EVERYDAY LIFE PRACTICES IN THE CONTEXT OF HEALTH PROMOTING PROGRAMMES}

Summary. In this text I present the results of research conducted as part of the project "Health in the opinions of children - childhood studies perspective" conducted by the Interdisciplinary Team for Childhood Studies at the University of Warsaw. The main goal of the project is to uncover the meanings young children (between 8 and 11 years of age) attribute to health, or the lack of it. I show how children, as social actors, cope with the modern demands regarding the body and their own new position as being responsible for passing knowledge about good eating habits and healthy lifestyles. I also present children's definitions of health and their understanding of unhealthy behaviour. One of the main subject of children's stories, next to the rather obvious associating health with sports, and eating fruits and vegetables, turned out to be the TV set, computer and other electronic devices. Therefore I ask about the meaning children give to media in the context of health. I focus on how they connect them to health, and on what linking the practice of TV watching with the subject of health tells us about the concepts of health and body. I also show how including television, computers and tablets in the health discourse is a result of a non-dualistic understanding of the body by children. For children health is inextricably linked to morality, education, and aesthetics. Even though the interviewed children adopt many of the narrations on health distributed by the educational institutions, and they seem to know how to eat and live healthy, they create health narrations of their own and on their own grounds. On one hand they are submissive receivers of the health promoting programmes (they know what is healthy), but on the other hand they stay members of their children's tribe, who realize their childhood by practicing what is considered unhealthy and "non-adult". The research gives us a picture of a divided child. A child that knows what to do to be healthy, but at the same time doing "unhealthy" things, which is allowed by the status of being a child.

Keywords: health, children, childhood studies, media. 